\title{
Development and using of some nanopesticide formulations against the conical snail, Cochlicella acuta, and the chocolate banded snail, Massylaea vermiculata
}

\author{
Al-kazafy Hassan Sabry ${ }^{1 *}$ (D) and Reham Fathey Ali $^{2,3}$
}

\begin{abstract}
Background: Nanopesticides are considered promising strategy in pest control. So, this strategy became an important new approach in pesticide formulations production. In this study, three traditional pesticide formulations (chlorfenapyr, imidacloprid and indoxacarb) were developed into nanoformulations. The toxicity of these nanoformulations was evaluated against the adults of the conical snail, Cochlicella acuta (Müller, 1774), and the chocolate banded snail, Massylaea vermiculata (Mohamed and Ali, Anim Biol J2(4):171-180, 2011).

Results: The results revealed that the nanosizes of nanoformulation nanoparticles were ranged between 220 and $534 \mathrm{~nm}$. The loading capacities of the selected pesticides on polymer were $65.3 \pm 6.4,62.8 \pm 5.3$ and $37.1 \pm 0.4 \%$ for nanochlorfenapyr, nanoimidacloprid and nanoindoxacarb, respectively. The nanochlorfenapyr was the most toxic against both the C. acuta and M. vermiculata followed by nanoindoxacarb and nanoimidacloprid. The $L_{50}, \mathrm{~S}$ of the nanoformulations were 6.1,7.7 and 14.9 ppm for chlorfenapyr, indoxacarb and imidacloprid, respectively.

Conclusions: These results cleared that the conical snails were more susceptible to all the tested pesticides than the chocolate banded snail, M. vermiculata. The efficacy of nanochlorfenapyr, nanoindoxacarb and nanoimidacloprid on conical snails (6.1,7.7 and 14.9 ppm, respectively) was about fourfold compared with M. vermiculata (23.1, 31.9 and $60.6 \mathrm{ppm}$, respectively).The results also revealed that the potency of nanoformulation used was not only by direct killing of tested snails but also by repellent effect.
\end{abstract}

Keywords: Nanopesticide formulations, Imidacloprid, Indoxacarb, Chlorfenapyr, Massylaea vermiculata, Cochlicella acuta

\section{Background}

Currently, there is an urgent need to develop a new approach of pesticide formulations. Therefore, using of alternative formulation may be resolving these side effects. Using of nanopesticide formulations is considered one of these solutions. The benefits of nanopesticides not only improve the pesticide efficacy but also improve the

\footnotetext{
*Correspondence: kazafysabry@yahoo.com

${ }^{1}$ Pests and Plant Protection Department, National Research Center, Cairo, Egypt

Full list of author information is available at the end of the article
}

solubility of the formulations used (Bombo et al. 2019). The nanopesticide formulations play an important role in reducing plant injury and economic loss by decreasing the quality and quantity of synthetic chemicals used in pest control (Syafrudin et al. 2021). Nanopesticide formulations can also reduce the environmental pollution and cost of treatment (Sabry and Hussein2021).

Terrestrial snails cause many injuries for important economic plants and field crops by damaging the leaves, fruits, roots, tubers and seeds (El-Deeb et al. 1999; Mohammed 2015; Ali and Robinson 2020; Ali and Ramdane 2020). Recently, the terrestrial snails are considered 
the main agricultural and economic pest in Egypt and causing reduction in crops yield (Nakhla and Tadros 1995; Sallam and El-Wakeil 2012). The conical snail, Cochlicella acuta, is considered one of the moderate hazard pests in Egypt. This pest causes damage to infested, grain crops and pastures by chewing or rasping the plant leaves (Hashem and El-Halawany 1996; Baker2002; Eshra 2004), while the chocolate banded snail, Massylaea vermiculata, which was previously known as Eobania vermiculata (Bouaziz-Yahiatene et al. 2017) is the most serious terrestrial snail to many vegetables fruits and field crops in many governorates in Egypt (Ismail 1997; Eshra 2013; Desoky et al. 2015; Ismail et al. 2017; Desoky 2018). This pest species was recorded in Europe (Puizina et al. 2013; Ronsmans and Van den Neucker 2016), Japan (Ueshima 2006), the USA (Roth and Sadeghian 2003), Australia (Blacket et al. 2016), and Egypt (Herbert 2010).

The conventional formulations of pesticides have many disadvantages such as environmental pollution, pest resistance, and underground water contamination. Nanopesticides formulations can be resolving these problems by reducing the pesticides concentrations and environmental contamination (Sabry and Hussein 2021).

Chlorfenapyr is a new pesticide that act as disruptor to the oxidative phosphorylation process and inhibit the (Adinosin triphosphate enzyme) ATP synthesis in respiration process in the target pest (Hollingworth and Gadelhak 1998). This pesticide was used against wide range of pests. Nanoformulation of this pesticide was developed and used against the adults of glossy clover snail, Monacha cartusiana (Sabry and Hussein 2021).

Imidacloprid is a neonicotinoids that acts on the nicotinic acetylcholine that are receptors in the nervous system (Buckingham et al. 1997). The nanoformulation of this pesticide was used against the Egyptian cotton leafworm, Spodoptera littoralis (Sabry et al. 2021), and glossy clover snail, Monacha cartusiana (Sabry and Hussein 2021).

Indoxacarb is a new pesticide used against many pests which acts by blocking of sodium channel this blocking leads to paralysis and death of treated pests (Wing et al. 2000). Nanoformulation of this pesticide was used against the Egyptian cotton leafworm, S. littoralis (Sabry et al. 2021).

This work aims to evaluate the efficacy of nanoformulations of chlorfenapyr, imidacloprid and indoxacarb against the adults of the conical snail, $C$. acuta, and the chocolate banded snail, $M$. vermiculata.

\section{Methods}

\section{Selected animal}

1. The adults of chocolate banded snail, Massylaea vermiculata, were collected from the farm belongs to

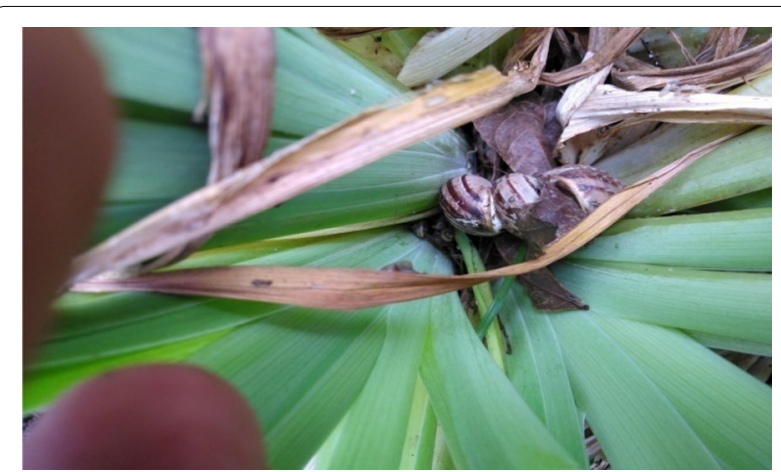

Fig. 1 Collecting of M. vermiculata adults

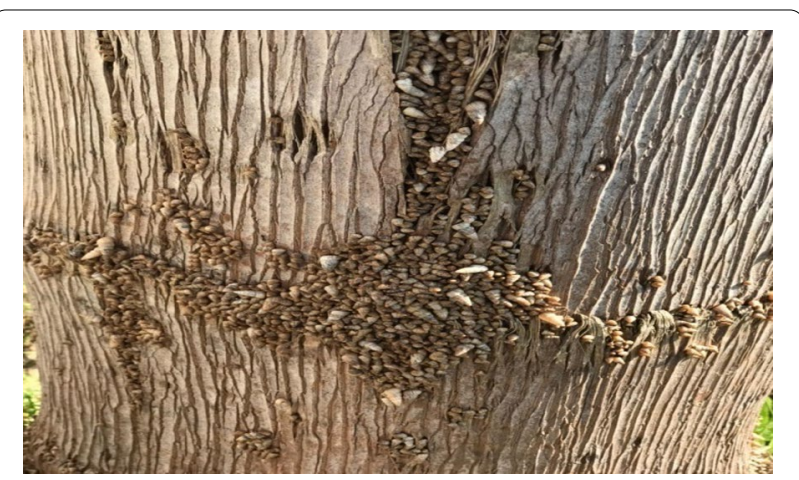

Fig. 2 Collecting of C. acuta adults

Faculty of Agriculture, Moshtohor, (Toukh Directorate), Banha University, Qalyubia Governorate (coordinates: $30^{\circ} 21^{\prime} \mathrm{N} 31^{\circ} 13^{\prime} \mathrm{E}$ ) (Fig. 1).

2. The adults of the conical snail, Cochlicella acuta, were collected from crop field farm at Belbeis, Sharkia Governorate (coordinates: $30^{\circ} 25^{\prime} \mathrm{N} 31^{\circ} 38^{\prime}$ E) (Fig. 2).

All collected samples of adult snails were transferred to the laboratory and then reared in plastic boxes $(30 \times 20 \times 10 \mathrm{~cm})$ with moist sandy loam soil. These adult snails were fed on lettuce, Lactuca sativa L. (Asteraceae), leaves and reared under laboratory conditions $\left(25 \pm 1{ }^{\circ} \mathrm{C}\right.$ and $75 \pm 5 \% \mathrm{RH})$.

\section{Selected pesticides}

1. Chlorfenapyr (Challenger ${ }^{\circledR} 36 \%$ SC) belongs to chemical family "pyrroles" and it is the first pyrrole submitted for US registration. This pesticide was obtained from Huaian Glory Chemical Co. Ltd. China. One-fifth of the recommended field rate of 
nanoformulation and two lower concentrations were used (Table 1).

2. Imidacloprid (Command ${ }^{\circ}{ }^{\circledR} 35 \% \mathrm{SC}$ ) produced by Vapco Company Jordan. This insecticide is related to neonicotinoids group. The recommended field rate is $250 \mathrm{ml} /$ feddan $\left(4200 \mathrm{~m}^{\mathrm{m}}\right)$. One-fifth of the recommended field rate of nanoformulation and two lower concentrations were used (Table 1).

3. Indoxacarb (Avaunt 15\% EC) produced by Du Pont De Nemours. Indoxacarb is related to a new insecticide class called oxadiazine and it acts as a sodium channel blocker. One-fifth of the recommended field rate of nanoformulation and two lower concentrations were used (Table 1).

\section{Preparation of the selected pesticide nanoformulations}

All tested pesticides formulations were converted to nanoformulations. Chitosan with a high molecular weight $(850 \mathrm{KDa})$ was used as a carrier (polymer) for active ingredient of all selected pesticides. All nanoformulations were developed according to Vaezifar et al. (2013). One gram of chitosan highly molecular weight was weighted and dissolved in acetic acid $(2 \% \mathrm{v} / \mathrm{v})$. The

Table 1 The concentrations of nanopesticide formulations used against C. acuta and M. vermiculata adults

\begin{tabular}{llll}
\hline Pesticides & \multicolumn{3}{l}{ Nanoformulations concentrations $(\mathbf{p p m})$} \\
\cline { 2 - 4 } & $\mathbf{C 1}^{\mathbf{a}}$ & $\mathbf{C 2}$ & $\mathbf{C 3}$ \\
\hline Chlorfenapyr & 20 & 10 & 5 \\
Imidacloprid & 36 & 18 & 9 \\
Indoxacarb & 30 & 15 & 7.5 \\
\hline
\end{tabular}

${ }^{a} \mathrm{C} 1$ : first concentration (one fifth of recommended field rate), $\mathrm{C} 2$ : the second concentration, C3: third concentration obtained mixture was transferred to magnetic stirrer for 15-20 min. After that $0.8 \%(\mathrm{w} / \mathrm{v})$ of tripolyphosphate (TPP) solution containing one-fifth of the field concentration of each tested pesticide individually was added to the chitosan mixture (chitosan + acetic acid) followed by 5-10 min of stirring. The obtained mixture was centrifuged at 10,000 RPM for $30 \mathrm{~min}$. The obtained pellet was collected and lyophilized to obtain nanoparticles in all selected pesticides. Photography of nanoparticles was achieved by scan electronic microscope (SEM) (Fig. 3).

After all tested pesticides were converted to nanoparticles, loading capacity (LC) of these nanoparticles calculated by (He et al. 2017) (Fig. 4):

$$
\text { Loading Capacity }(\mathrm{LC})=\frac{\text { Mass of loaded pesticide }}{\text { Mass of pesticide nanoparticles }} \times 100
$$

Loading capacity means that the mass percentage of the selected pesticides that loaded on carrier used (polymer) compare with the active ingredient in conventional formulation.

The method of loading capacity determined is carried out by $30 \mathrm{mg}$ of the obtained nanosamples (all selected pesticides nanoparticles) were weighed and dissolved in $50 \mathrm{ml}$ of acetonitrile. This mixture was shaking overnight at a constant temperature to completely dissolve the chitosan nanoparticles. After that, the obtained solution was filtered, and the mass concentration of each pesticide nanoformulation in acetonitrile was examined by HPLC (Agilent 1260 system with a WATO45905 C18 column) under a detection wavelength of $278 \mathrm{~nm}$. The loading capacity of each nanoparticle was calculated by division of the mass of loaded pesticides on mass of pesticide nanoparticles.

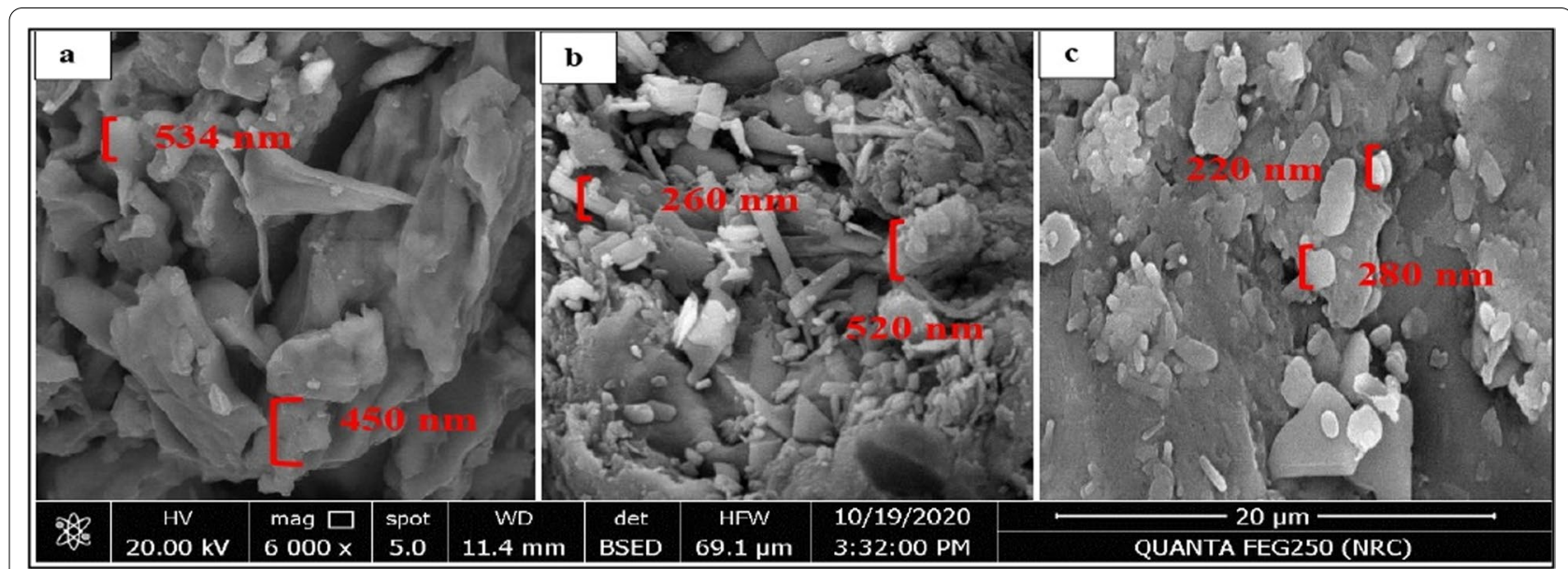

Fig. 3 The nanoparticles of chlorfenapyr (a), imidacloprid (b) and indoxacarb (c) under scan electronic microscope (SEM) 


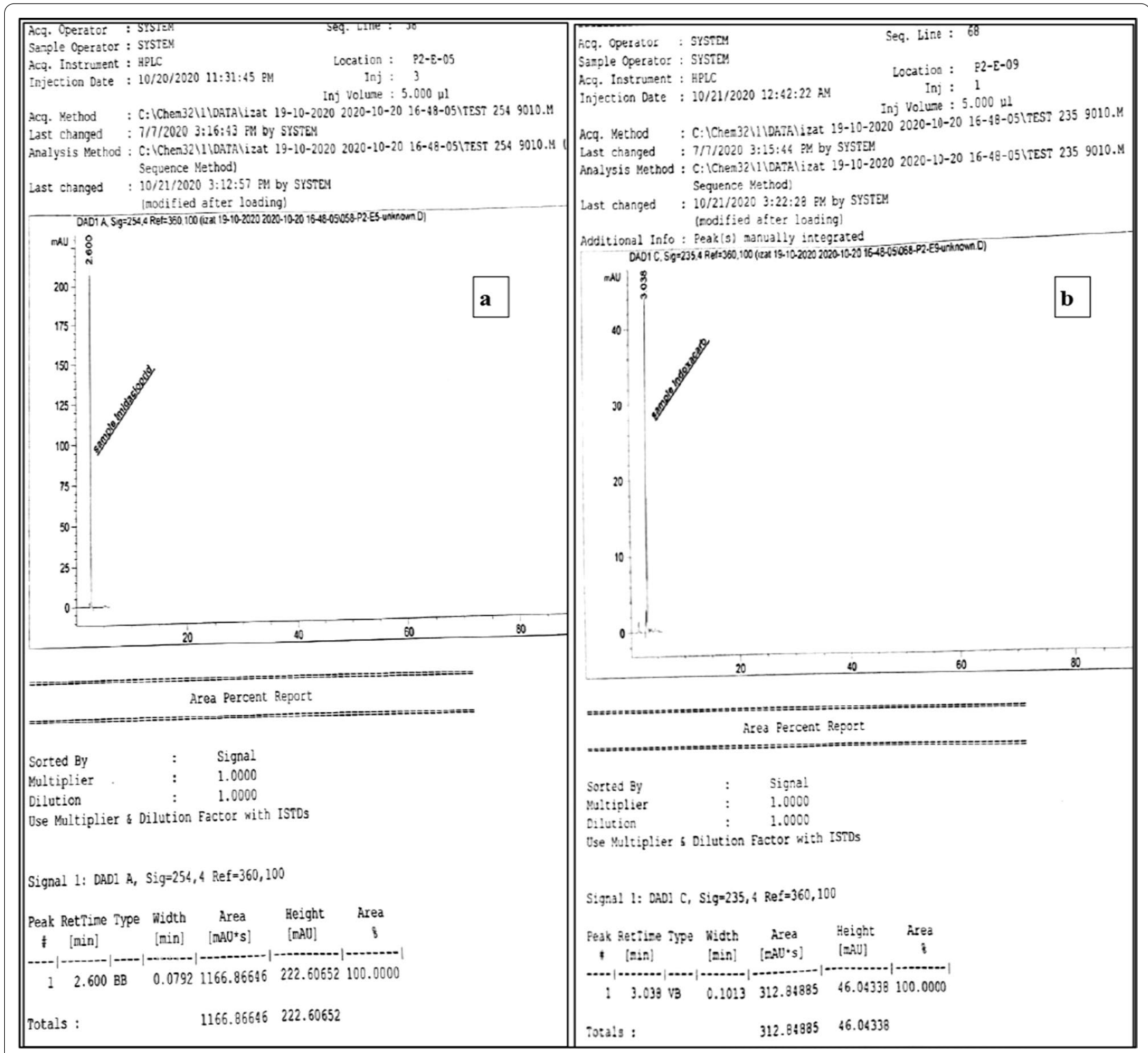

Fig. 4 Loading capacity of imidacloprid (a) and indoxacarb (b)

\section{Bioassay}

Three concentrations of each nanoformulation were used (Table 1). Every concentration has three replicates. Every replicate includes ten healthy and starved adults of the selected snails in plastic box. The bioassay test was carried out by dipping test that the fresh lettuce leaves were dipped in each concentration and then the health adult snails were fed on. All tested snails were kept under laboratory conditions $\left(25 \pm 1{ }^{\circ} \mathrm{C}\right.$ and $75 \pm 5 \% \mathrm{RH})$. The fresh leaves were checked daily and replaced with fresh one. The percentages of mortality were evaluated after 1, 3, 5 and 10 days of treatment. The lethal of $50 \%$ of tested population $\left(\mathrm{LC}_{50}\right)$ was calculated by Finney (1971)

\section{Statistical analysis}

The data were analyzed by variance test (ANOVA) via Randomized Complete Block Design (RCBD) ( $F$ test) and analysis of variance (one ways classification ANOVA) followed by a least significant difference (LSD) at 5\% (Costat Statistical Software 1990). 


\section{Results}

The activities of chlorfenapyr, imidacloprid and indoxacarb against both the adults of Cochlicella acuta and Massylaea vermiculata were evaluated under laboratory condition. The efficacy of all tested pesticides showed differences between the $C$. acuta and M. vermiculata.

\section{Activity of chlorfenapyr, imidacloprid and indoxacarb nanoformulations against the adults of conical snails, $C$. acuta}

Data in Table 2 show that the first concentration (the highest concentration that equal one-fifth of the recommended field rate) of chlorfenapyr is the most effective against $C$. acuta followed by imidacloprid and indoxacarb.

The percentages of mortality are 93.3, 83.3 and 73.3, respectively (Table 2). These results also are obtained with the second concentration (the half of first concentration). With the third concentration (one-fourth of the first concentration), chlorfenapyr is the most effective followed by indoxacarb and imidacloprid (Fig. 5).

This difference leads to the $\mathrm{LC}_{50} \mathrm{~s}$ of the tested pesticides are 6.1, 7.7 and 14.9 ppm for chlorfenapyr, indoxacarb and imidacloprid, respectively (Table 2). The statistical analysis shows that there is no significant difference between chlorfenapyr and imidacloprid with all concentrations. The results also revealed that there is a significant difference between chlorfenapyr and indoxacarb. The less significant difference are 10.9, 10.9 and 12.2 with the first, second and third concentrations.

\section{Efficacy of chlorfenapyr, imidacloprid and indoxacarb nanoformulations against the adults of chocolate banded snail, M. vermiculata}

Data in Table 3 show that all tested pesticides have medium effects against $M$. vermiculata adults (Table 3 and Fig. 6). The percentages of mortality with first concentration (the highest concentration) in all tested

Table 2 Toxicity of some nanopesticide formulations against the conical snail, C. acuta

\begin{tabular}{|c|c|c|c|c|c|}
\hline \multirow[t]{2}{*}{ Pesticides } & \multicolumn{3}{|c|}{ Concentrations and percent of mortalities \pm SE } & \multirow[t]{2}{*}{ Slope \pm SE } & \multirow[t]{2}{*}{$\mathrm{LC}_{50}$ and fiducial limits } \\
\hline & First concentration & Second concentration & Third concentration & & \\
\hline Chlorfenapyr & $93.3 \pm 5.8^{a}$ & $66.7 \pm 5.8^{a}$ & $43.7 \pm 5.8^{\mathrm{a}}$ & $2.6 \pm 0.4$ & $6.1(5.0-7.0)$ \\
\hline Imidacloprid & $83.3 \pm 5.8^{\mathrm{ab}}$ & $56.7 \pm 5.8^{\mathrm{ab}}$ & $30.0 \pm 0.0^{\mathrm{ab}}$ & $2.5 \pm 0.3$ & $14.9(12.7-17.2)$ \\
\hline Indoxacarb & $73.3 \pm 5.8^{b}$ & $46.7 \pm 5.8^{b}$ & $33.3 \pm 5.8^{\mathrm{a}}$ & $1.7 \pm 0.3$ & $7.7(6.2-9.4)$ \\
\hline Control & $6.7 \pm 5.8^{c}$ & $3.3 \pm 5.8^{c}$ & 0.0 & & \\
\hline$F$ values* & $138.3^{* * *}$ & $70.0^{* * *}$ & $25.1^{* * *}$ & & \\
\hline LSD & 10.9 & 10.9 & 12.2 & & \\
\hline
\end{tabular}

*Means under each concentration sharing the same letter in a column are not significantly different at $P<0.05$

***Means the difference between these data is very significant

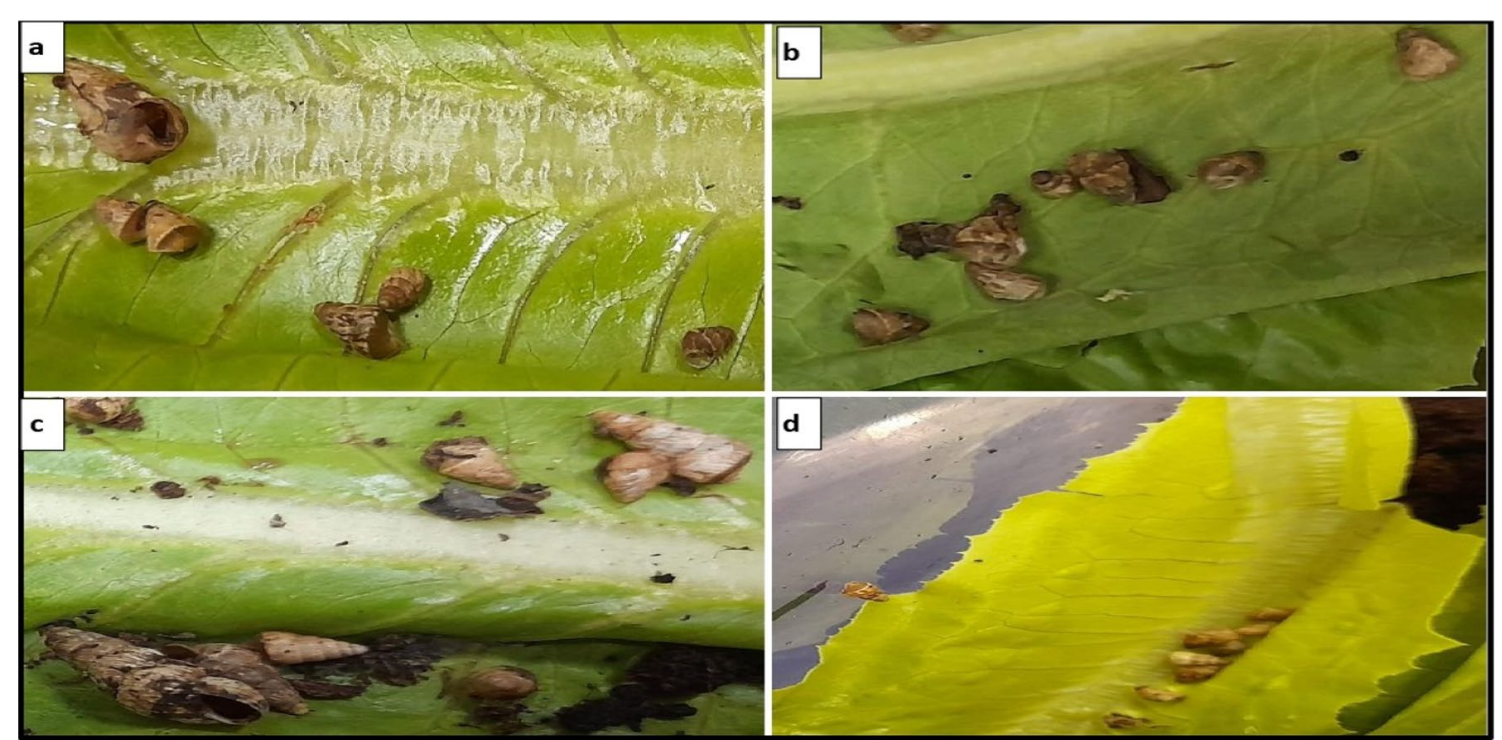

Fig. 5 Effect of nanoformulations of chlorfenapyr (a), imidacloprid (b), indoxacarb (c) compared with untreated (control) (d) on the conical snails adults 
Table 3 Toxicity of some nanopesticide formulations against the chocolate banded snail, M. vermiculata

\begin{tabular}{|c|c|c|c|c|c|}
\hline \multirow[t]{2}{*}{ Pesticides } & \multicolumn{3}{|c|}{ Concentrations and percent of mortalities \pm SE } & \multirow[t]{2}{*}{ Slope \pm SE } & \multirow[t]{2}{*}{$\mathrm{LC}_{50}$ and fiducial limits } \\
\hline & First concentration & $\begin{array}{l}\text { Second } \\
\text { concentration }\end{array}$ & Third concentration & & \\
\hline Chlorfenapyr & $46.7 \pm 5.8^{\mathrm{a}}$ & $23.3 \pm 5.8^{\mathrm{a}}$ & $13.3 \pm 5.8^{\mathrm{a}}$ & $1.8 \pm 0.3$ & $23.1(17.7-37.9)$ \\
\hline Imidacloprid & $33.3 \pm 5.8^{b}$ & $23.3 \pm 5.8^{\mathrm{a}}$ & $10.0 \pm 10.0^{\mathrm{a}}$ & $1.6 \pm 0.4$ & $60.6(41.5-143.9)$ \\
\hline Indoxacarb & $36.7 \pm 5.8^{b}$ & $16.7 \pm 5.8^{\mathrm{a}}$ & $10.0 \pm 0.0^{\mathrm{a}}$ & $1.4 \pm 0.3$ & $31.9(19.7-119.4)$ \\
\hline Control & $0.0^{c}$ & $3.3 \pm 5.8^{b}$ & $0.0^{b}$ & & \\
\hline Fvalues** & $49.2^{* * *}$ & $8.0^{* *}$ & $3.1^{\mathrm{ns}}$ & & \\
\hline LSD & 9.4 & 10.9 & 10.9 & & \\
\hline
\end{tabular}

**Means under each concentration sharing the same letter in a column are not significantly different at $P<0.05$

***Means the difference between these data is very significant

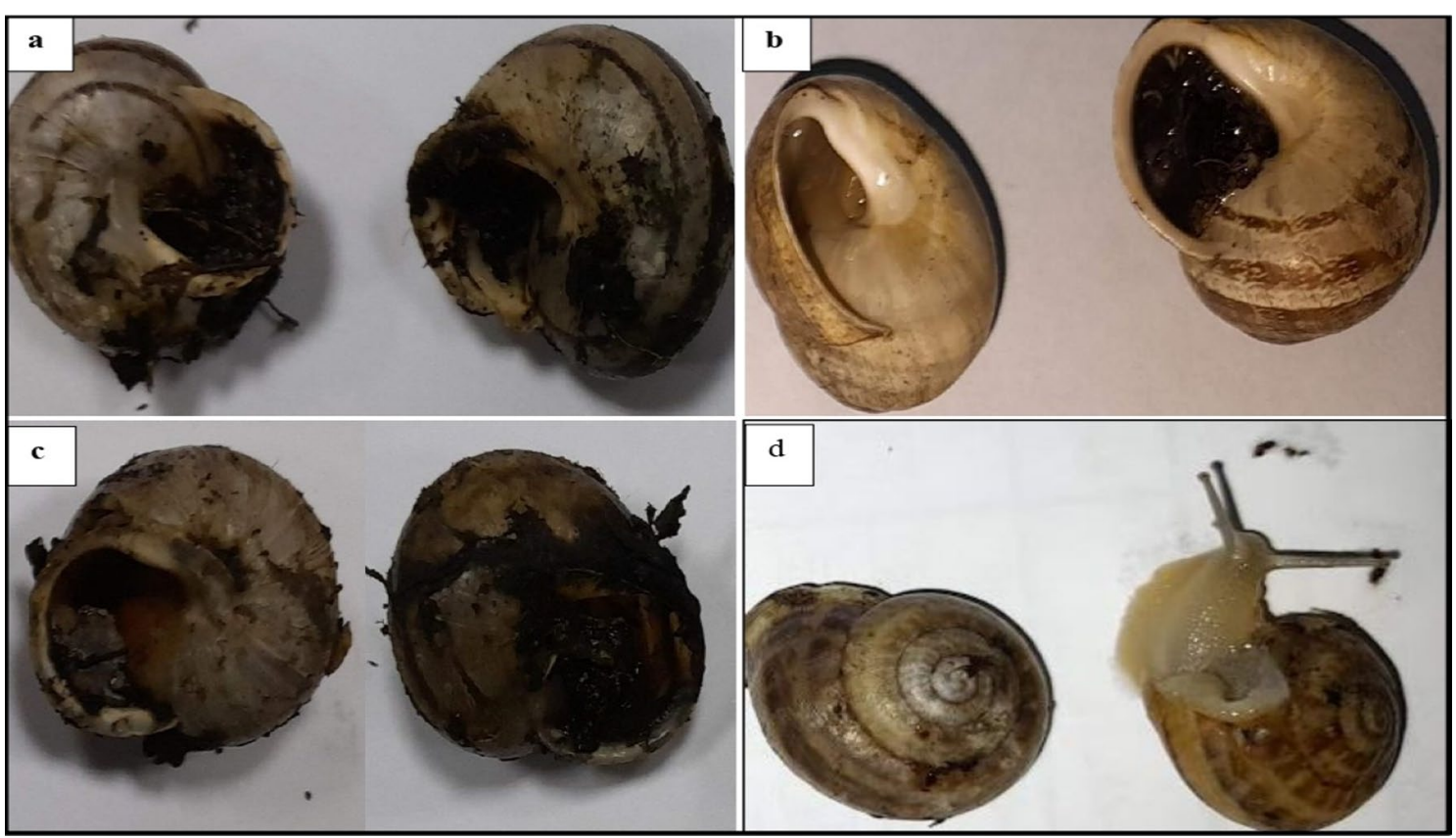

Fig. 6 Effect of chlorfenapyr (a), imidacloprid (b) and indoxacarb (c) on the adults of M. vermiculata compared with the control (d)

pesticides are 46.7, 33.3 and $36.7 \%$ with chlorfenapyr, imidacloprid and indoxacarb, respectively.

This means that the highest percent of mortality did not exceed $46.7 \%$. According to the $\mathrm{LC}_{50}$ chlorfenapyr is the most effective pesticide against $M$. vermiculata followed by indoxacarb and imidacloprid. The $\mathrm{LC}_{50, \mathrm{~s}}$ are 23.1, 31.9 and $60.6 \mathrm{ppm}$, respectively. The statistical analysis shows that there is a significant difference between the first concentration (one-fifth of recommended field rate) of chlorfenapyr and the first concentration in other tested pesticides.

The LSD is 9.7. On the other hand, there is no significant difference among all tested pesticides with the second and third concentrations. All tested pesticides showed a significantly different effect compared with the control.

\section{Discussion}

Cochlicella acuta snails are considered one of the most destructive pest causing damage to palm trees, citrus orchards and ornamental plants (Mohamed and Ali 2011). The toxic action of all tested nanopesticides was very fast against the adult of $C$. acuta snail species. The adults of $C$. acuta were died after $1 \mathrm{~h}$ of treatment and the survived adults were stopped feeding (Fig. 5). The similar result was found by Sabry et al. (2021). The obtained results found that the nanoformulation of indoxacarb was more effective than nanoimidacloprid against the 
second instar larvae of Spodoptera littoralis. Sabry and Hussein (2021) found that the nanochlorfenapyr was more effective than nanoimidacloprid against the glossy clover snails, Monacha cartusiana. Chlorfenapyr was the most effective compared with other used pesticides this may be due to the nature of mechanism of action of chlorfenapyr. This pesticide inhibits the adinosin triphosphate enzyme synthesis and therefore inhibits the respiration process.

The Massylaea vermiculata adults were moderately affected by the nanoformulations of the tested pesticides. These results were consistent with Ali et al. (2014). The obtained results found that the silver nanoparticles reduced the $M$. vermiculata by $20 \%$ under laboratory conditions. Khidr (2018) evaluated the efficacy of nanochitosan against the adults of $M$. vermiculata. The $\mathrm{LC}_{50}$ was $1.4 \mathrm{ppm}$. Mohamed et al. (2021) used the nanosilica against the adults of $M$. vermiculata. The nanosilica reduced the population of $M$. vermiculata. Hussein and Sabry (2019) found that indoxacarb was more effective against $M$. vermiculata adults than abamectin and spiromesifen. The lethal concentration for $50 \%$ of population $\left(\mathrm{LC}_{50}\right)$ of indoxacarb was $58.6 \mathrm{ppm}$.

\section{Conclusions}

The obtained results showed that the adults of C. acuta were more susceptible to the tested nanopesticides than the adults of $M$. vermiculata. The $\mathrm{LC}_{50}$ of chlorfenapyr was $6.1 \mathrm{ppm}$ with the $C$. acuta adults compared with $23.1 \mathrm{ppm}$ with the $M$. vermiculata adults. This means that the susceptibility of C. acuta was 4-times approximately. These results also found with both imidacloprid and indoxacarb nanoparticles. Hussein and Sabry (2019) found that the $\mathrm{LC}_{50}$ of indoxacarb normal formulation was $58.6 \mathrm{ppm}$. The obtained results showed that the indoxacarb nanoformulation was $7.7 \mathrm{ppm}$. This result means that the nanoformulation $(7.7 \mathrm{ppm})$ was more effective against the adults of $M$. vermiculata than the normal formulation (58.6 ppm). Consequently, using of nanopesticides can reduce the pesticides risk in the environment by reducing the concentrations used.

\section{Abbreviations}

$\mathrm{LC}_{50}$ : Lethal concentrations for $50 \%$ of pest population; LSD: Less significant difference; TPP: Tripolyphosphate; RCBD: Randomized Complete Block Design.

\section{Acknowledgements}

The authors wish to express their deep thanks to the National Research Centre, Giza, Egypt, for affording all the requirements and supports to achieve this work.

\section{Authors' contributions}

SKH designed the workplan, carried out the laboratory evaluation, data analysis and writing the manuscript; ARF collecting the samples from different places, laboratory experiment and writing the paper. Both authors read and approved the final manuscript.

\section{Funding}

The technical work of this research was funded financially by the Scientific Research Projects Sector-National Research Centre, Egypt. Project No. 12050118

\section{Availability of data and materials}

The datasets used and/or analyzed during the current study are available from the corresponding author on reasonable request.

\section{Declarations}

Ethics approval and consent to participate

Not applicable.

\section{Consent for publication}

Not applicable.

\section{Competing interests}

The authors declare that they have no competing interests.

\section{Author details}

${ }^{1}$ Pests and Plant Protection Department, National Research Center, Cairo, Egypt. ${ }^{2}$ Department of Zoology and Agricultural Nematology, Faculty of Agriculture, Cairo University, El - Gammaa St., Giza 12613, Egypt. ${ }^{3}$ Faculty of Organic Agriculture, Heliopolis University for Sustainable Development, 3 Cairo-Belbeis Desert Rd, El-Nahda, Second Al Salam, P. O.: 3020, Cairo 11785 , Egypt.

Received: 14 September 2021 Accepted: 27 December 2021 Published online: 20 January 2022

\section{References}

Abd El-All EM, Arafa OE (2019) Biological parameters of the conical snails, Cochlicella acuta (MÜLLER, 1774) (Gastropoda: Cochlicellidae) under laboratory conditions. J Plant Prot Path Mansoura Univ 10(1):53-56

Ali RF, Ramdane R (2020) Taxonomic key as a simple tool for identifying and determining the abundant terrestrial snails in Egyptian fields (Gastropoda, Pulmonata: Succineidae, Geomitridae, Helicidae, Hygromiidae). Egypt Acad J Biol Sci B Zool 12(2):173-203

Ali RF, Robinson DG (2020) Four records of new to Egypt gastropod species including the first reported tropical leather leaf slug, Laevicaulis alte (d'A. de Férussac, 1822) (Pulmonata: Veronicellidae). Zool Ecol 30(2):138-156

Ali SM, Yousef NMH, Nafady NA (2014) Application of biosynthesized silver nanoparticles for the control of land snail Eobania vermiculata and some plant pathogenic fungi. J Nanomater 18904:1-10

Baker GH (2002) Helicidae and hygromiidae as pests in cereal crops and pastures in southern Australia. In: Barker GM (ed) Molluscs as crop pests. CAB International, New York, pp 193-215

Blacket MJ, Michael S, Linda S, Mallik BM (2016) Introduced helicidae garden snails in Australia: morphological and molecular diagnostics, species distributions and systematics. Rec Aust Mus 68(3):99-116

Bombo AB, Pereira AES, Lusa MG, De Medeiros OE, De Oliveira JL, Campos EVR, De Jesus MB, Oliveira HC, Fraceto LF, Mayer JLS (2019) A mechanistic view of interactions of a nanoherbicide with target organism. J Agric Food Chem 67:4453-4462

Bouaziz-Yahiatene H, PfarrerB M-B, Neubert E (2017) Revision of Massylaea Möllendorff, 1898 (Stylommatophora, Helicidae). Zoo Keys 694:109-133

Buckingham SD, Lapied B, Corronc HL, Grolleau F, Sattelle DB (1997) Imidacloprid actions on insect neuronal acetylcholine receptors. J Exp Biol 200:2685-2692

Costat Statistical Software (1990) Microcomputer program analysis version 4.20.Cohort Software, Berkeley

Desoky ASS (2018) Identification of terrestrial gastropods species in Sohag Governorate, Egypt. Arch Agric Environ Sci 3(1):45-48

Desoky ASS, Sallam AA, Abd El-Rahman TMM (2015) First record of two species from land snails, Monacha obstracta and Eobania vermiculata in Sohag governorate, Egypt. Dir Res J Agric Food Sci 3(11):206-210 
El-Deeb HI, Wilson M, Eshara EH (1999) Ecological studies on certain land snails infests some Economic crops at Beheira Governorate, Egypt. In: Proc 2nd Int Conf Pest Cont Mansoura, Egypt, pp 19-28

Eshra EH (2013) Survey and distribution of terrestrial snails in fruit orchards and ornamental plants at Alexandria and EL-Beheira governorates, Egypt. Alex Sci Exch J 34(2):242-248

Eshra EH (2004) Studies on terrestrial mollusca at some governorates of West Delta with special reference to its integrated management. Ph.D. Thes Fac Agric Al Azhar Univ Egypt, p 225

Finney DJ (1971) Probit analysis. Cambridge University Press, Cambridge, p 333 Hashem AG, El-Halawany ME (1996) Egypt. In: Morse JG, Luck RF, Gumpf DJ (eds) Citrus pest problems and their control in the Near East. FAO Plant ProducProtec Paper, vol 135, pp 25-42

He Q, Zhang H, Li LX, Zhou XT, Li JP, Kan CY (2017) Preparation and properties of lambda-cyhalothrin polyurethane drug-loaded nanoemulsions. RSC Adv 7:52684-52693

Herbert DG (2010) The introduced terrestrial mollusca of South Africa. SANBI Biodiversity Series 15. South African National Biodiversity Institute, Pretoria, p 108

Hollingworth RM, Gadelhak GG (1998) Mechanisms of action and toxicity of new pesticides that disrupt oxidative phosphorylation. Rev Toxicol 12:253-266

Hussein MA, Sabry KH (2019) Assessment of some new pesticides as molluscicides against the adult and eggs of chocolate banded snail, Eobania Vermiculata. Bull NRC 43(75):1-5

Ismail SA (1997) Ecology, biology and control of certain terrestrial snails infesting some vegetables and field crops in Sharkia Governorate. Egypt: Ph.D. Thesis, FacAgricZagUniv, p 130

Ismail SAA, Issa MA, Shettaia SZS, Khattab MM (2017) Dispersal of the land snail Eobania vermiculata in citrus orchards in Sharkia governorate. J Plant Prot Pathol Mansoura Univ 8(4):177-180

Khidr EK (2018) Chitosan and nano-chitosan efficacy against the land snails, Eobania vermiculata and Monacha obstructa (Muller) under laboratory conditions. Egypt Acad J Biol Sci 10(2):15-25

Mohamed MI, Ali RF (2011) Life cycle and growth rates of the conical snail Cochlicella acuta (Müller, 1774) (Gastropoda: Cochlicellidae). Anim Biol J 2(4):171-180

Mohamed GR, El-Shewy AM, Morsy AR (2021) Toxicity of nanosilica particles on Eobania vermiculata and their effects on biochemical changes in rats. Egypt Acad J Biol Sci 13(1):217-226

Mohammed GR (2015) Incidence of land snails inhabiting different vegetation at some governorates in North-East of Delta Egypt. J Plant Prot Pathol Mansoura Univ 6(6):899-907

Nakhla JM, Tadros AW (1995) Studies on the seasonal abundance of land snails on date palm shoots in Sharkia Governorate. Egypt J Res 73(2):347-355

Puizina J, Fredotović Ž, Šamanić I, Šušnjara T, Kekez L, Cukrov D, Pleslić G (2013) Phylogeography of the land snail, Eobania vermiculata (O.F. Müller, 1774) (Gastropoda: Pulmonata) along the Croatian Coast and Islands. J Entomol Zool Stud 1(4):23-31

Ronsmans J, Van den Neucker T (2016) A persistent population of the chocolate-band snail Eobania vermiculata (Gastropoda: Helicidae) in Belgium. Bel J Zool 146(1):66-68

Roth B, Sadeghian PS (2003) Checklist of the land snails and slugs of California. Santa Barbara Museum of Natural History, Contributions in Science, vol 3, pp 1-81

Sabry KH, Hussein MA (2021) Relative toxicity of some nanopesticides and their conventional formulations against the glossy clover snails, Monacha Cartusiana. J Biol Nat 13(1):54-60

Sabry KH, Salem HAN, Metwally HM (2021) Development of imidacloprid and indoxacarb formulations to nanoformulations and their efficacy against Spodoptera littoralis (Boisd). Bull Nat Res Cent 45(16):1-7

Sallam A, El-Wakeil N (2012) Biological and ecological studies on land snails and their control. Integ Pest Manag Pest Cont Cur Fut Tact 18:413-444

Syafrudin M, Kristanti RA, Yuniarto A, Hadibarata T, Rhee J, Al-onazi WA, Algarni TS, Almarri AH, Al-Mohaimeed AM (2021) Pesticides in drinking water-a review. Int J Environ Res Public Health 18:468

Ueshima R (2006) The effect of pest control on Eobania vermiculata (Gastropoda: Helicidae) in Urayasu, Chiba Prefecture, Japan. Chir 36(4):123

Vaezifar S, Razavi S, Golozar MA, Karbasi S, Morshed M, Kamali M (2013) Effects of some parameters on particle size distribution of chitosan nanoparticles prepared by ionic gelation method. J Clust Sci 24:891-903
Wing KD, Sacher M, Kagaya Y, Tsurubuchi Y, Mulderig L, Connair M, Schnee M (2000) Bioactivation and mode of action of the oxadiazine indoxacarb in insects. Crop Prot 12:537-545

\section{Publisher's Note}

Springer Nature remains neutral with regard to jurisdictional claims in published maps and institutional affiliations.

\section{Submit your manuscript to a SpringerOpen ${ }^{\circ}$ journal and benefit from:}

- Convenient online submission

- Rigorous peer review

- Open access: articles freely available online

- High visibility within the field

- Retaining the copyright to your article

Submit your next manuscript at $\boldsymbol{\nabla}$ springeropen.com 